\title{
Occurrence and levels of persistent organic pollutants (POPs) in wild and farmed tilapia (Oreochromis niloticus) from Lake Kariba, Zambia: possible impact on fish health
}

\section{Chalumba Simukoko}

University of Zambia School of Veterinary Medicine

\section{Eliezer Mwakalapa}

Mbeya University of Science and Technology

Kaampwe Muzandu

University of Zambia School of Veterinary Medicine

\section{Stephen Mutoloki}

Norwegian University of Life Sciences Faculty of Veterinary and Biosciences: Norges miljo- og biovitenskapelige universitet Veterinaerhogskolen

\section{Øystein Evensen}

Norwegian University of Life Sciences Faculty of Veterinary and Biosciences: Norges miljo- og biovitenskapelige universitet Veterinaerhogskolen

\section{Erik Ræder}

Norwegian University of Life Sciences Faculty of Veterinary and Biosciences: Norges miljo- og biovitenskapelige universitet Veterinaerhogskolen

\section{Mette Müller}

Norwegian University of Life Sciences Faculty of Veterinary and Biosciences: Norges miljo- og biovitenskapelige universitet Veterinaerhogskolen

\section{Anuschka Polder ( $\nabla$ anuschka.polder@nmbu.no)}

Norwegian University of Life Sciences Faculty of Veterinary and Biosciences: Norges miljo- og biovitenskapelige universitet Veterinaerhogskolen Jan Ludvig Lycke

Norwegian University of Life Sciences Faculty of Veterinary and Biosciences: Norges miljo- og biovitenskapelige universitet Veterinaerhogskolen

\section{Research Article}

\section{Keywords:}


DOI: https://doi.org/10.21203/rs.3.rs-1272893/v1

License: (c) (1) This work is licensed under a Creative Commons Attribution 4.0 International License. Read Full License 
1 Title: Occurrence and levels of persistent organic pollutants (POPs) in wild and farmed tilapia

2 (Oreochromis niloticus) from Lake Kariba, Zambia: possible impact on fish health.

3 Chalumba Kachusi Simukoko a, b, Eliezer Brown Mwakalapa ${ }^{\text {c }}$, Kaampwe Muzandu ${ }^{\mathrm{b}}$, Stephen

4 Mutoloki $^{\mathrm{d}}$, Øystein Evensen ${ }^{\mathrm{d}}$, Erik Magnus Ræder ${ }^{\mathrm{a}}$, Mette Bjørge Müller ${ }^{\mathrm{e}}$, Anuschka Polder $5 \quad \mathrm{a}^{*}$, Jan Ludvig Lyche ${ }^{\mathrm{a}}$

$6 \quad{ }^{a}$ Department of Paraclinical Sciences, Norwegian University of Life Sciences, P. O. Box 8146 7 Dep, N-0033, Oslo, Norway

$8{ }^{\mathrm{b}}$ Department of Biomedical Sciences, School of Veterinary Medicine, University of Zambia, 9 P. O. Box 32379 Lusaka, Zambia

$10{ }^{c}$ Department of Natural Sciences, Mbeya University of Science and Technology, P. O. Box 11 131, Mbeya, Tanzania

$12{ }^{\mathrm{d}}$ Department of Basic Sciences and Aquatic Medicine, Section of Aquatic Medicine and 13 Nutrition, Norwegian University of Life Sciences, P.O Box 8146 Dep, NO-0033 Oslo, Norway

$14{ }^{\mathrm{e}}$ Department of Production Animal Clinical Sciences, Section for Experimental Biomedicine, 15 Norwegian University of Life Sciences, P.O Box 8146 Dep, NO-0033 Oslo, Norway

\section{Abstract}

18 The current study was carried out to determine occurrence and levels of persistent organic 19 pollutants (POPs) in wild and farmed tilapia (Oreochromis niloticus) in Lake Kariba, Zambia, 20 and possible implications for fish health. Concentrations of organochlorine pesticides (OCPs), 21 polychlorinated biphenyls (PCBs), polybrominated diphenyls (PBDEs), hexabromocyclododecane (HBCDD) and perfluoroalkyl substances (PFASs) were determined 
in liver samples of tilapia. Concentrations of POPs in wild tilapia were in general higher than in farmed tilapia, however, concentrations of DDTs and PCBs in wild tilapia foraging near the fish farms were more in the range of the farmed fish. The highest median $\sum$ DDTs (93 and 81 $\mathrm{ng} / \mathrm{g} \mathrm{lw}$ ) were found in wild tilapia from sites 1 and 2, respectively $165 \mathrm{~km}$ and $100 \mathrm{~km}$ west of the farms. DDE/DDT ratios seem to indicate recent exposure to DDT. The highest median of $\sum_{17} \mathrm{PCBs}(3.2 \mathrm{ng} / \mathrm{g} \mathrm{lw})$ and $\sum_{10} \mathrm{PBDEs}(8.1 \mathrm{ng} / \mathrm{g} \mathrm{lw})$ were found in wild tilapia from site 1 and 2, respectively. The dominating PCB congeners were PCB-118, $-138,-153$ and -180 and for PBDEs, BDE-47, -154, and -209. Of PFASs, only PFOS, PFDA and PFNA were detected in wild fish with highest median PFOS levels in site $1(0.66 \mathrm{ng} / \mathrm{g} \mathrm{ww})$. The PCB and BDE

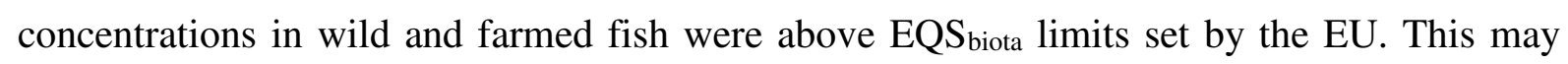
suggest a risk to the fish species and threaten biodiversity.

\section{Introduction}

Fish serves as a major source of proteins to most people in the world and is essential for food security and sustainability (FAO 2020). The growing human population has led to increased demand for fish, leading to overexploitation of wild fisheries and depletion of some fish stocks. Human fish consumption was estimated at 151.2 million tonnes in 2016, while production from capture and aquaculture fisheries were 91 and 80 million tonnes, respectively (FAO 2018; Golden et al. 2017). Apart from being a source of protein, aquaculture is also a source of income for many people estimated at USD 231.6 billion in 2018 (FAO 2018). Since the 1980s aquaculture has seen a constant growth. Currently, African aquaculture industry is undergoing a rapid growth (FAO 2018). Zambia is the sixth-largest producer of farmed fish in Africa, and biggest producer of tilapia in the Southern African Development Community (SADC) (Genschick et al., 2017). Zambia produced 85,000 metric tonnes of fish according to the Department of Fisheries, of which 30,000 tons was produced in fish farms (WorldFish 2022). Despite all benefits, increasing of fish farming may have negative impact on the environment due to release of organic effluents, chemicals and antibiotics in the waterbodies and by acting as a source of diseases or genetic contamination of wild species (Berg et al. 1992; Jarić et al. 2011; Kishimba et al. 2004; Li et al. 2011; Mwakalapa. et al. 2018; Nonga et al. 2011; Polder et al. 2014; Ssebugere et al. 2014; Subasinghe 2005). 
Pollution of aquatic environments by persistent organic pollutants (POPs) can affect fish and human health (Barni et al. 2016; Burreau et al. 2004; Jarić et al. 2011; Rodriguez-Hernandez et al. 2017). POPs include compounds like organochlorine pesticides (OCPs), polychlorinated biphenyls (PCBs), brominated flame retardants (BFRs) such as, polybrominated diphenyl ethers (PBDEs) and hexabromocyclododecane (HBCDD) and Perfluoroalkyl substances (PFASs) (Deribe et al. 2011; Rodriguez-Hernandez et al. 2017). Anthropogenic activities such as industries, mining, agriculture and waste from human settlements are sources of POPs (Covaci et al. 2008; Henry and Kishimba 2006; Lyche et al. 2015; Nieuwoudt et al. 2009; Santonen et al. 2017). Their semi volatile nature coupled with long environmental half-lives results in long-range transport and global distribution (De Boer et al. 1994; Nie et al. 2006; Panseri et al. 2019; Squadrone. et al. 2013). Except for PFASs, which are protein bound, POPs are lipophilic and can therefore accumulate in fatty tissues of organisms including fish, and bioaccumulate in the food chain (Burreau et al. 2004; Deribe et al. 2011; Letcher et al. 2010; Sharma et al. 2009; Squadrone et al. 2013). Despite the Stockholm Convention of 2001, protecting human health and the environment from POPs (Stockholm Convention 2021), they are still present in most parts of the world (Ashraf 2017).

The growing aquaculture industry in Africa may be threatened by the presence of POPs and other contaminants in the water and fish. Therefore, to enable sustainable aquaculture development, it is of key importance to gain knowledge on toxicological risk factors and the potential adverse effects of pollutants and other environmental factors on fish health. Contaminant residues in fish may also represent a food safety risk. Environmental stressors including harmful chemical contaminants and biotoxins and other water quality parameters such as $\mathrm{pH}$, oxygenation and eutrophication, have impact on health in wild stocks and farmed fish. Lack of knowledge about levels, sources, environmental behaviour and toxicity, hampers evidence-based decision-making regarding implementation of protective measures. The current study was carried out to establish the occurrence and concentrations of POPs in wild and farmed tilapia from Lake Kariba, Zambia, with emphasis on fish health.

\section{Materials and methods}

\section{Description of sampling area and species}

Nile tilapia (Oreochromis niloticus) were collected from Lake Kariba, located on the southern 
man-made lake in the Zambezi River basin spanning across three districts (Sinazongwe, Gwembe and Siavonga) on the Zambia side. The lake is $320 \mathrm{Km}$ long and covers an estimated area of $5400 \mathrm{Km}^{2}$, with an average depth of 29 meters. The water flow is from west to east where a hydroelectric power plant is located at the Kariba Gorge (Fig. 1). Five locations (Sites 1, 2 and 3, and farms 1 and 2) were selected for this study. Site 1 is in Sinazongwe district with human activities that include coal mining, commercial fishing, crop, livestock, and wildlife farming, with a population of 98,246 (Zambia census 2010). Site 2 is in Gwembe district with agricultural activity (crop and livestock), commercial fishing and a population of 50,136 (Zambia census 2010). Sites 1 and 2 are situated respectively $165 \mathrm{~km}$ and $100 \mathrm{~km}$ west of the farms. Site 3, which is in Siavonga district, has agricultural activities with crop, livestock, crocodile and commercial fish farms and a feed processing plant. It has a population of 85,811 (Zambia census 2010). Fish farms 1 and 2 are also located in Siavonga district. The farms use cages for rearing tilapia on the lake. Nile tilapia is a fish native to river Nile, which has been spread across the world (Eknath AE and Hulata G 2009). It is found as both wild and farmed fish. It is an omnivorous species that feeds on plankton and higher plants, like algae. Tilapia thrives in tropical and subtropical climates with environmental temperatures of $9-42^{\circ} \mathrm{C}$, living in shallow waters. It is a fast grower and is fairly resistant to harsh conditions making it favourable for aquaculture.

The climate around Lake Kariba is sub-tropical with a cool and hot dry season from May to October and the wet season between November and April. Annual rainfall ranges from 400 to $700 \mathrm{~mm}$ whilst temperature ranges between $13^{\circ} \mathrm{C}$ and $40^{\circ} \mathrm{C}$. Rainfall and intra-seasonal distribution of rain vary greatly from year to year. Due to these climatic conditions, the southern part of Zambia is a drought-prone area and rain-fed agriculture is highly unpredictable.

\section{Ethical consideration and permission for the study}

The study proposal was approved by the University of Zambia, School of Veterinary Medicine research committee. Local district fisheries and Veterinary officers were consulted and involved in the conducting of the study in their areas. Managers at the fish farms gave their permission for samples to be collected from their farms. The permission to transport samples from Tanzania to Norway was granted by The Ministry of Agriculture, Livestock and Fisheries and The Norwegian Food Safety Authority. 
115 A total of 142 wild and farmed tilapia samples were collected from June to July 2017. 116 Physicochemical parameters ( $\mathrm{pH}$, temperature, conductivity, and total dissolved solutes) were 117 measured in all sites (not shown). Live wild tilapia were bought from fishermen as they pulled 118 in their catch from the water. The fish were then placed in a container containing ice water and 119 transported to the shore for dissection. Farmed tilapia were sampled by dip netting and placed 120 in containers containing water. The length and sex of the fish were recorded (Table 1A, 1B). 121 The size of the fish was sometimes considerably different within the study sites. The scale used 122 in the field could only weigh fish up to $1 \mathrm{~kg}$. Therefore, only length was used in statistical analyses. Using forceps and scalpel blades, the fish was dissected on a board and liver tissue removed and placed in clean $15 \mathrm{ml}$ Eppendorf tubes then placed on ice in a cooler box. The samples were then transported to the University of Zambia, Veterinary Medicine School, and stored at $-20^{\circ} \mathrm{C}$. The frozen samples were later transported on ice to the Laboratory of Environment Toxicology at the Norwegian University of Life Science in Oslo, Norway and stored at $-20^{\circ} \mathrm{C}$ until analyses.

Sample analysis of OCPs, PCBs and BFRs,

130 A total of 82 liver samples were selected and pooled based on size (Table 1A). Each homogenate contained two or three liver samples. Only male fish was included for POP analyses. Before analyses the samples were thawed at room temperature and protected from light during the analyses. The samples were analysed for organochlorinated pesticides (OCPs): hexachlorobenzene (HCB), $\alpha, \beta$ - and $\gamma$-hexachlorocyclohexanes (HCHs), heptachlor, oxychlordane, trans-chlordane, cis-chlordane and trans-nonachlor (CHLs), mirex, bis-2,2-(4chlorophenyl)-1,1,1- trichloroethane ( $p, p^{\prime}$-DDT) and its metabolites $p, p^{\prime}$-DDE, $p, p^{\prime}$-DDD and $o, p^{\prime}$-DDT, polychlorinated biphenyls PCBs: (PCB-101, -105, -110, -118, -128, -138, -141, $149,-151,-153,-156,-170,-180,-183,-194,-206$ and -209 ( $\left.\sum{ }_{17} P C B s\right)$, and brominated flame retardants (BFRs):, polybrominated diphenyl ethers PBDEs: BDE -47, -99, -100, -153, -154, 183, -196, -202, -206 ( $\sum{ }_{9}$ PBDEs) and BDE-209 ( $\sum{ }_{10}$ PBDEs is $\sum{ }_{9}$ PBDEs + BDE-209), and hexabromocyclododecane (HBCDD). Mirex, PCB -28, -52, -56, -66, -74, -87, -99, -114, -136,

$142-137,-157$, and -187; BDE-28, -207, and -208 were analysed but were not detected above LOD.

143 Those compounds were not included in any data analyses. 
146 Individual liver samples $(\mathrm{N}=26)$ from the same sampling areas and same catch were analysed

147 for perfluoroalkyl substances (PFAS): perfluorohexane sulfonate (PFHxS), perfluorooctane

148 sulfonamide (FOSA) and perfluorooctane sulfonate (PFOS)* and 9 PFCAs: perfluorohexanoic

149 acid (PFHxA), perfluoroheptanoic acid (PFHpA), perfluorooctanoic acid (PFOA),

150 perfluorononanoic acid (PFNA)*, perfluorodecanoic acid (PFDA)*, perfluoroundecanoic acid

151 (PFUdA), perfluorododecanoic acid (PFDoA), and perfluorotridecanoic acid (PFTrDA),

152 perfluorotetradecanoic acid (PFTeDA). Because of low sample amounts available, some

153 female fish were included for PFAS analyses (Table 1B). Compounds marked with * were 154 included in $\sum_{3}$ PFAS. Other PFAS components were not detected in levels >LOD and were not 155 used in any data analyses further.

157 The analytical method for analysing of OCs was first described by Brevik (1978) and modified 158 by Polder et al (2014), in which full details are described. In short, the method is based on

159 repeated fat extraction of the homogenised liver with acetone, cyclohexane and water, using an

160 ultrasonic homogenizer and separation of the fat using centrifugation. Lipid determination was 161 done gravimetrically using $1 \mathrm{~mL}$ aliquot of the fat extract. The rest of the extract was treated 162 with $96 \% \mathrm{H}_{2} \mathrm{SO}_{4}$ for cleaning of fat and the final extract was concentrated before GC analyses. 163 Before extraction, internal standards PCB -29, -112 and -207 (1000 $\mu \mathrm{g} / \mathrm{mL})$ (Ultra-Scientific, 164 RI, USA); $20 \mu \mathrm{L}$ of BDE $-77,-119,-181$, and ${ }^{13} \mathrm{C}_{12}-209,{ }^{13} \mathrm{C}_{12}-\mathrm{TBBP}-\mathrm{A}(500 \mu \mathrm{g} / \mathrm{mL})$ 165 (Cambridge Isotope Laboratories, Inc., MA, USA) were added in all the samples. During the 166 analyses the samples were protected from light and amber GC-vials were used.

\section{Chemical analyses of PFASs}

168 The analytical method was described by Grønnestad et al (2017). In short, internal standards 169 (Wellington laboratories) were added to 0,5 g homogenized liver samples. Extraction was 170 performed twice with $5 \mathrm{ml}$ methanol and an ultrasonic probe sonicator followed by centrifugation. The supernatants were combined and cleaned with approximately $0,2 \mathrm{~g}$ graphitized carbon (EnviCarb). Finally, the samples were evaporated to near dryness and

173 dissolved in $500 \mu 1$ Methanol / water 1:1. Analysis of the samples on HPLC-MS resulted in 174 substantial matrix effects, suggesting that further cleanup was necessary. An additional 0,2 $\mathrm{g}$

175 EnviCarb was added to the samples followed by filtration with Spin-X centrifuge filters 
176 (Corning). The EnviCarb and filters were washed with 500 $\mu 1$ methanol and the filtrates were

177 combined and concentrated to dryness and finally reconstituted in $200 \mu 1 \mathrm{MeOH}$.

178

180

181

182

183

184

185

186

187

188

189

190

191

192

193

194

195

196

197

198

199

200

201

202

203

204

Instrumental analysis

\section{Separation and detection of the POPs}

OCPs, PCBs and BFRs were separated and detected using GC-MS methods as described by Mwakalapa et al. (2018) and Polder et al. (2014), on a HRGC (Agilent 6890 Series) coupled to a MS detector (Agilent 5975C Agilent Technologies) which was operated in negative chemical ionization (NCI) mode with selected ion monitoring (SIM). The OCPs and PCBs (injection volume of $1 \mu \mathrm{L}$ ) were separated on a DB-5 MS column (J\&W Scientific, Agilent Technologies) (60 m, $0.25 \mathrm{~mm}$ i.d., $0.25 \mathrm{~mm}$ film thickness). BFRs (injection volume of $2 \mu \mathrm{L}$ ) were separated on a DB-5 MS column (J\&W Scientific, Agilent Technologies) (30 m, 0.25 mm i.d., $0.25 \mathrm{~mm}$ film thickness). The separation and identification of BDE-209 (injection volume of $10 \mu \mathrm{L}$ ) were performed on a GC-5-MS (Agilent 6890 Series/5973Network) configured with a programmable temperature vaporization (PTV) injector (Agilent Technologies) equipped with a DB-5-MS column (10 m, $0.25 \mathrm{~mm}$ i.d., $0.10 \mathrm{~mm}$ film thickness); J\&W Scientific, Agilent Technologies). For all components, five-to eight-point linear calibration curves were used and calculations were done within the linear range for the component. OCPs, PCBs and BFRs were monitored using negative chemical ionization (NCI) in selected ion monitoring (SIM).

\section{Separation and detection of the PFASs}

Samples were analyzed on an Agilent 1200 HPLC-system coupled to an Agilent 6460 Triple

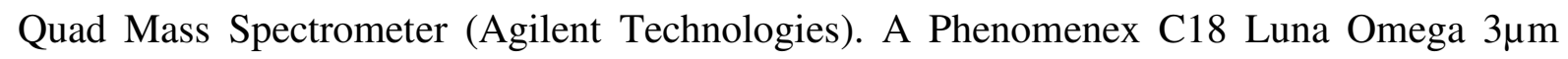
100x4,6 mm (Phenomenex) was used as the analytical column and a $50 \mathrm{~mm}$ version of the same column was installed between the pump and the injector to act as a delay-column to reduce blank contamination. The injected amount was $20 \mu 1$.

\section{Quality Assurance (QA)/ Quality control (QC)}

The chemical analysis of the liver samples was conducted at the Laboratory of Environmental Toxicology at the Norwegian University of Life Sciences in Oslo, Norway. The laboratory is accredited for testing chemicals in biological samples by the Norwegian accreditation according to the requirement of the NS-EN ISO/IEC 17025 (TEST 137). 
OCPs, PCBs, BFRs. Every analytical series included one blind sample of non-spiked salmon trout (Salmo trutta), two samples of spiked salmon trout for recovery, three procedural blanks of solvents and the laboratory's own reference material of the blubber of a harp seal (Pagophilus groenlandicus). The analytical quality was successfully approved by routinely analysing different Certified Reference Materials (CRMs). Within the same period, the laboratory successfully participated in Arctic Monitoring and Assessment Program (AMAP) ring test for PCBs, OCPs and PBDEs in human serum 2016, and Quasimeme 2016, round 1: QOR126BT, QOR127BT, QBC046BT, QBC047BT for OCs in fish muscle, fish liver and shellfish tissue inter-laboratory studies. The limits of detections (LOD) for individual analytes were defined as 3 times the noise level of each analyte. The LODs (ng/g wet weight, ww) ranged from 0.003 to 0.166 for OCPs, 0.003 to 0.101 for PCBs and 0.003 to 0.036 for BFRs. The relative recoveries were $82-137 \%$ for OCPs, $92-127 \%$ for PCBs, and $68-120 \%$ for BFRs.

217 For PFASs, every analytical series included three blanks of solvent, two samples of spiked

218 Atlantic cod (Gadus morhua) for recoveries and one blind sample of non-spiked Atlantic cod.

219 LOD was calculated as 3 times the noise in the chromatogram. The LOD for PFAS ranged 220 between $0.093 \mathrm{ng} / \mathrm{g}$ ww to $0.706 \mathrm{ng} / \mathrm{g}$ ww. Matrix-matched calibration curves ranged from 0 $22150 \mathrm{ng} / \mathrm{ml}$ and were Linear with $\mathrm{R}^{2}>0,99$, except for PFTrDA. The analytical quality of the method was assessed by including an inter-laboratory test (AMAP) in the analysis of samples.

\section{Statistical data analysis}

224 Detection rate was defined as percentage of samples with a detectable value, i.e., above LOD. 225 The compounds with detection rate above 50\% were reported with descriptive statistics and 226 further included in the statistical analyses. Levels below LOD were replaced with 1/2 LOD. 227 Compounds with a detection rate lower than 50\% were reported with range and were not 228 included in further statistical analyses. For this latter group, the levels below LOD were replaced with a value of 0.0001 when calculating the sum of the compound group for all results

230 presented, Stata SE/16 (Stata Corp., College Station, TX, USA) was used for statistical 231 analysis. Normality of the data was tested using Shapiro-Wilk. If data from one of the locations 232 failed the Shapiro-Wilk test, the data of all locations were log-transformed. The nonparametric 233 Kruskal-Wallis test were used as the present data failed Shapiro-Wilk after being log234 transformed. Dunn`s post-hoc test was applied for pairwise comparisons between the locations, 235 with and without Bonferroni corrections for multiple comparison. Spearman rank correlation 
was used to assess the correlation between variables. The statistical significance level was set at $\mathrm{p}<0.05$.

\section{Results}

\section{Fish characteristics}

240 Fish weight and length correlated strongly for fish below $1 \mathrm{~kg}$ for both wild fish $(\mathrm{r}=0.93)$ and 241 farmed fish ( $\mathrm{r}=0.92)$. Since fish weight above $1 \mathrm{~kg}$ was not specified, fish length was used as

242 indicator of fish size. Fish from farm 1 were significantly longer (mean $36 \mathrm{~cm}),(\mathrm{p}<0.05)$ than 243 the other locations (Table 1A, Fig. 2). The median liver lipid contents (\%) of farmed fish 244 from farm $1(8.8 \%)$ and $2(7.5 \%)$ were significantly higher than for wild fish from site $2(4.9$ $245 \%)$, and farm 1 was significantly higher than site 1 (4.1\%). There was also a significant 246 difference in liver lipid content between the wild fish at site 2 and 3 (7.2\%). Length of the 247 individual fish for PFAS analyses were all in the same range (Table 1B).

Occurrence and levels of OCPs, PCBs, BFRs

249 HCB and $p, p$ '-DDE were the OCPs detected in $100 \%$ of the liver samples. Median concentrations of HCB were significantly higher in wild fish from site 3 (Table 2B) compared to site 2 and in farm 1 and 2 (Fig. 2). Of the $\mathrm{HCHs}, \gamma-\mathrm{HCH}$ (lindane) and $\alpha-\mathrm{HCH}$ were detected in $77 \%$ and $50 \%$ of the samples, respectively. The highest median concentration of $\sum \mathrm{HCHs}$ was $0.05 \mathrm{ng} / \mathrm{g} \mathrm{lw}$ in site 3 . The $\gamma-\mathrm{HCH}$ was the dominant $\mathrm{HCH}$, contributing $56 \%, 69 \%$ and $65 \%$ to $\sum \mathrm{HCHs}$ in wild fish from site 1,2 and 3, and $79 \%$ and $58 \%$ in fish from farm 1 and 2 (Fig. 3). $\alpha-\mathrm{HCH}$ contributed between $21-34 \%$ to the $\sum \mathrm{HCH}$ and $\beta-\mathrm{HCH}$ between $1-14 \%$. The median $\sum$ HCHs was significantly higher in site 3 compared to site 1,2 and farm 2 (Fig. 2). DDTs were the most abundant OCPs in all the locations with the highest median concentrations of $\sum$ DDTs in wild fish from site 1 and 2 (93 and $81 \mathrm{ng} / \mathrm{g}$ lw) (Table 2B). $P, p^{\prime}$-DDD and $p, p$ 'DDT were detected in $93 \%$ and $73 \%$, while $o, p$ '-DDD and $o, p$ '-DDT were detected in $17 \%$ and $3 \%$ of the samples, respectively. $P, p$ '-DDE and $\sum$ DDTs were significantly higher in site 1 and 2 compared to farm 1 and 2, while site 3 was only significantly higher than farm 2 (Fig.2). The contribution of $p, p$ '-DDE to the $\sum$ DDTs was highest in wild fish from site 1 and 2 (48\% and $61 \%$ ), but lower in wild fish from site 3, and farmed fish from farm 1 and 2 (46\%, $30 \%$ and $31 \%$ ) (Fig. 3). In farm 1 and 2, the contribution of p,p'-DDD to the $\sum$ DDTs was higher than that of $p, p^{\prime}-\mathrm{DDE}$ with $63 \%$ and $68 \%$, respectively (Fig. 3). The ratio of $p, p^{\prime}-\mathrm{DDE} / p, p^{\prime}-$ 
DDT was highest in wild fish from site 2 and farmed fish from farm 2 and lowest in wild fish from site 3. Trans-nonachlor was detected in 73\%, and cis-nonachlor, cis-chlordane and transchlordane in only 17\%, $13 \%$ and $7 \%$ of the samples, respectively. Trans-Nonachlor contributed $66-87 \%$ to $\sum$ CHLs. $\sum$ CHLs were not significantly different between any of the locations. Mirex and heptachlor were not detected in any of the samples. PCBs were detected in all locations in low concentrations. PCBs-118, -138, -153 and -180 were the most abundant PCBs and found in $53 \%, 60 \%, 90 \%$ and $77 \%$ of the samples, contributing average $8 \%, 14 \%, 25 \%$ and $16 \%$ to $\sum_{17} \mathrm{PCBs}$ respectively (Fig. 3). The highest median concentration of $\sum_{17} \mathrm{PCBs}$ was found in site 1 at $3.3 \mathrm{ng} / \mathrm{g}$ lw <site $3<$ site $2<$ farm $1<$ farm 2 (Table 2B, Fig. S1). Median $\sum{ }_{17}$ PCBs was significantly higher in site 1 compared to 2 and farm 1 and 2. Site 3 was significantly higher compared to site 2 and farm 2 (Fig. S1).

PBDEs were detected in all samples, except one. BDE-47, -99, -154, and 209 were the most abundant BDEs detected in $70 \%, 30 \%, 57 \%$ and $97 \%$ of the samples. BDE-209 dominated the PBDE pattern and contributed average $84 \%$ to $\sum{ }_{10}$ PBDEs (Fig. 3). The highest median concentration of $\sum{ }_{10} \mathrm{PBDEs}$ (including BDE-209) was $8.1 \mathrm{ng} / \mathrm{g}$ lw in site 2 . Median $\sum_{9} \mathrm{PBDEs}$ (excluding BDE-209) were not significantly different between the locations, however the median $\sum{ }_{9}$ PBDEs was significantly lower in farm 2 compared to site 1,2,3 and farm 1 (Fig. 2). HBCDD was only detected in one sample from farm 1 , with a concentration of $0.27 \mathrm{ng} / \mathrm{g} \mathrm{lw}$.

Occurrence and levels of PFASs

285

286

287

288

289

290

291

292

293

PFOS, PFDA and PFNA were the only PFASs detected in levels >LOD in individual wild fish (Table 2B). No PFASs were detected in site 3, farm 1 or farm 2. PFOS and PFNA were detected in $100 \%$ and $40 \%$ and in $100 \%$ and $40 \%$ in wild fish from site 1 and 2, respectively and PFNA was detected in $20 \%$ in site 1 and 2. The highest median level of PFOS (0.66 ng/g ww) was found in wild fish from site 1 while highest median level of PFDA (0.37 ng/g ww) was found in site 2 (Table 3; Fig. S1).

\section{Correlations}

Spearman correlations coefficients for the main compounds HCB, $\sum$ DDTs, $\sum$ PCBs, $\sum$ BDEs and $\sum$ BDE including BDE-209 are presented in Table S2. Strong correlations were found between HCB, $\sum$ DDTs and $\sum$ PCBs ( $>0.86$ ), and between $\sum$ DDTs and $\sum$ BDE including BDE209 ( $\mathrm{r}=0.86)$ in site 1 . In site 2, only $\sum$ BDEs and $\sum$ BDE including BDE-209 showed strong correlations $(\mathrm{r}=0.84)$. In site 3, $\sum$ DDTs, $\sum$ PCBs, $\sum$ BDEs and $\sum$ BDE including BDE-209 
strongly correlated $(r>0.8)$, and $\sum$ PCBs and $\sum$ BDEs with $r=0.93$. In site 4 , HCB and $\sum B D E s$ showed strong correlations ( $\mathrm{r}=0.86)$, and in site 5, HCB and $\sum$ BDEs $(\mathrm{r}=0.86)$ and $\sum \mathrm{DDT}$ and $\sum$ PCBs $(\mathrm{r}=0.88)$.

301 Compared to recommend Environmental quality standards (EQS) from European commission

302 most of the POPs were below the limits for fish except for $\sum{ }_{10} \mathrm{BDE}$ (mean $0.04-0.36 \mathrm{ng} / \mathrm{g}$ 303 ww) which was higher than the EQS limits of $0.0085 \mathrm{ng} / \mathrm{g}$ set the EU (European Commission 304 2013; Jürgens et al. 2015).

\section{4. Discussion}

306 Food security is a global issue and farming of fish is essential as supplement to wild fish 307 industry for the growing global population (FAO 2020). The main goal in fish farming industry 308 is to obtain high quality fish for sale in short time. The fish must fulfil criteria set by health 309 authorities, as regards to nutritional value as well as to the presence of environmental 310 contaminants/pollutants (Saavedra et al 2017; Skåre et al. 2014). Fish feed is therefore specially 311 composed for the purposes of fast growth, high content of nutrients and low content of 312 pollutants. As expected, the farmed fish had significantly higher liver lipid content compared 313 to the wild fish (Table 2, Fig 2), which indicates good conditions for the farmed fish. Spillage 314 of feed and organic waste from the cages into the environment around the farms makes more 315 nutrients available to wild fish (Ballester-Moltó et al 2017; Bustnes et al. 2010; Varol. 2019).

316 Fish from site 3 forages around the fish farms and shows significantly higher fat content than 317 in wild fish from site 2, confirming that wild fish in site 3 makes use of nutrient spill from the 318 fish farms (Table 2). There is also a possibility that farmed tilapia escape from the cages and 319 thus being caught as wild fish, thus influence the fat content of fish in site 3 (Azevedo-Santos 320 et al. 2011).

322 DDTs were the dominant OCPs in both wild and farmed fish liver tissues from Lake Kariba. 323 Wild fish had significantly $(\mathrm{p}<0.05)$ higher levels of median $\sum$ DDTs compared to the farmed 324 fish (Table 2, Fig. 2). This was similar to findings in other studies (Berg et al. 1992; Mwakalapa 325 et al. 2018) (Table 5). The countries around Lake Kariba (Zambia and Zimbabwe), have 326 historically been influenced by use of DDT for vector control in combatting malaria and tsetse 
control operations in addition to agriculture (Berg et al. 1995). Lake Kariba was filled with water in 1958-1963. Because the flooded areas were earlier treated with DDT, the sediments of the Lake will still be a reservoir of DDT residues. Due to long half-life of DDT and different metabolism under anaerobic conditions, DDT and its metabolites originating from the time before the Lake was filled, may still contribute to exposure of living organisms in Lake Kariba today (Berg et al. 1995; Brevik 1996). In addition, DDT may have entered the Lake Kariba by run-off and atmospheric deposition (Banda and Mundia 2009; Berg et al. 1992; Ssebugere et al. 2009). Use of DDT was banned globally in the 1970s but is still allowed for use in indoor residual spraying (IRS) and for production of insecticide-treated mosquito nets (ITN) (WHO 2011). Due to these campaigns, the levels of DDT are expected to decrease in the environment of the South African region. Biodegradation of DDT results mainly in the more persistent metabolites $p, p$ '-DDE and $p, p$ '-DDD. In the present study, the contribution of $p, p$ '-DDE to $\sum$ DDTs was highest in wild fish from site 1 and 2 but decreased eastwards in wild fish from site 3 (Fig. 3). In the farmed fish, p,p'-DDD was contributing most to $\sum$ DDTs (Table 2, Fig. 3). Higher ratio of $p, p^{\prime}-\mathrm{DDD} / \mathrm{p}, \mathrm{p}^{\prime}-\mathrm{DDE}$ is related to anaerobic degradation in soil and sediments and uptake in plant roots (Buah-Kwofie et al. 2017; Chen et al. 2007). Periods of drought, or increased water flow in the farming area may contribute to an increased bioavailability of chemical pollutants stored in sediments below the fish cages. However, this needs to be studied further. The ratios of $p, p^{\prime}$-DDE/ $p, p$ '-DDT were lower in several wild fish from site 1 and site 3, indicating relatively recent use of DDT in the area (Table 5). In addition, one of the pooled samples from site 1 contained $o, p$ '-DDT, strengthening this observation. The $p, p^{\prime}-\mathrm{DDE} / p, p^{\prime}-\mathrm{DDT}$ ratios in fish from farm 2 were higher than in farm 1 and indicate stronger relationship to historic use of DDT (Ssebugere et al. 2009). Levels of mean $\sum$ DDTs in the wild tilapia were lower than those reported in Lake Victoria (Henry and Kashimbi 2006; Polder et al. 2014), but higher than from other areas (Deribe et al. 2011; Gbeddy et al. 2015; Mdegela et al. 2009) (Table 5). Farmed tilapia in the present study had similar levels of mean $\sum$ DDTs to those reported from Lake Kariba, Zimbabwean side, by Berg et al. (1992) (Table 4).

The second dominant OCP, HCB, was detected in low levels below the EQS set by the EU (Table 4). Median levels of HCB were significantly higher in wild fish from site 3 compared to site 2 and farm 1 and 2 (Table 2B, Fig. 2). Previously, Berg et al (1992) found larger differences between wild and farmed fish in Lake Kariba. HCB was used as a fungicide, in rubber synthesis and wood preservation among other uses, but is banned under the Stockholm Convention (Stockholm Convention 2021). The low levels observed may reflect a general 
background level related to long range atmospheric transport from emission of industries at far distance (Polder et al. 2014). Levels of HCB in the current study were in the same range as levels reported in tilapia liver from Tanzania by Mwakalapa et al. (2018) and Mdegela et al (2009), but lower than those reported by Polder et al. (2014) in tilapia muscle, and much lower than in brown trout in Norway reported by Lyche et al. (2018) (Table 5).

365

366

367

368

369

370

371

372

373

374

375

376

377

378

379

380

381

382

383

384

385

386

387

388

389

390

391

Although levels of HCHs generally were low in all study sites, the median $\sum \mathrm{HCHs}$ was significantly higher in wild fish from site 3 than in site 1 and 2 and in farm 2 (p<0.05) (Fig. 2). Median $\mathrm{KHCHs}$ in farmed fish from farm 1 was not significantly different from site 3, suggesting that $\mathrm{HCH}$ in site 3 and farm 1 have a common source. Lindane $(\gamma-\mathrm{HCH})$ was used as an insecticide on fruit and vegetable crops, for seed treatment and treatment of lice and scabies, mainly in West-European and Asian countries (Vijgen et al. 2006). Non-scientific confirmed information suggests use of locally produced lindane as a fishing technique in Ghana. Pure lindane is contaminated with $\alpha-\mathrm{HCH}$ and $\beta-\mathrm{HCH}$ of which $\beta-\mathrm{HCH}$ is the most persistent isomer. Due to regulations, levels of lindane are decreasing. The patterns of $\mathrm{HCHs}$ found in this study may thus reflect historic use of the technical mixture combined with relatively recent use of $\gamma-\mathrm{HCH}$. The general $\mathrm{HCH}$ levels in tilapia from Lake Kariba were in the same range as those reported by Berg et al. (1992), Mwakalapa et al. (2018) and Polder et al. (2014) in Tanzania, but much lower than findings in South Africa by Verhaert et al. (2017) and in Ghana by Gbeddy et al. (2015) (Table 5).

Trans-Nonaklor was the dominant chlordane found in low levels in the present study. Chlordanes are banned compounds and are no longer used as insecticides (Stockholm Convention 2021). Mean levels of $\sum$ CHL were less than those reported by Polder et al. (2014) and Mdegela et al. (2009) in Tanzania and Gbeddy et al. (2015) in Ghana. Mirex and Heptachlor are also banned substances and were below detection limit in all samples (Table $\mathrm{S}$ $1.1)$.

PCBs were detected in very low levels in wild and farmed tilapia and those levels were in the same range as in other East African countries (Deribe et al. 2011; Kidd et al. 2004; Mwakalapa et al. 2018), but lower than in tilapia from Tanzania and Ghana, and other fish from South Africa and Norway (Polder et al. 2014; Wepener et al. 2012; Asantae et al. 2013; Lyche et al. 2018). Occurrence and levels of PCB (17.2 ng/g lw) in wild tilapia from Lake Tanganyika was suggested to be related to human activities and small local industries (Polder et al. 2014). Wild tilapia from site 1 showed the highest mean $\sum_{17} \mathrm{PCBs}$ (3.2 ng/g lw) (Table 2B). Emission from 
a coal mine in the area may be a possible source. Other possible sources of PCBs in countries with limited historic use of PCBs are waste burning, transportation, household heating, discharges from cities, sewage processing, e-waste burning, hospital waste incineration, and transformer oil (Pius et al. 2019). In the present study only PCB-118, -138, -153 and -180 were detected in more than $50 \%$ of the samples. These congeners are the most persistent PCBs and contributed more than $60 \%$ to $\sum_{17}$ PCBs. Dominance of PCB-153, PCB-180 and PCB-138 was similar to findings in other studies (Asante et al. 2013; Hayward et al. 2007; Mwakalapa et al. 2018; Polder et al. 2014). In the present study, PCB-118 was detected in $72 \%$ of the wild tilapia, but only in $25 \%$ of the farmed tilapia (data not shown). PCB-118 is a mono-ortho substituted PCB and has a toxic equivalent factor of 0.00003 (Van den Berg et al. 2006). In the study by Polder et al. (2014) PCB-118 was only detected in one tilapia sample from Lake Victoria and one from Lake Babati in Tanzania. It seems thus, that the environment in Lake Kariba is exposed to a different historic PCB mixture than in other studies in the region. The finding of significantly higher $\sum_{17} \mathrm{PCBs}$ in fish from site 1 and $3(0.92 \mathrm{ng} / \mathrm{g} \mathrm{lw})$ than in the nearby farms $1(0.27 \mathrm{ng} / \mathrm{g} \mathrm{lw})$ and $2(0.19 \mathrm{ng} / \mathrm{g} \mathrm{lw})$, may be related to higher age of the wild fish, rather than higher exposure to unknown sources.

PBDEs were used as flame retardants in thermoplastics (computer and TV housing), textiles, foams, furniture, electronics, building materials and interiors of cars, busses, and airplanes (Covaci et al. 2008; Lyche et al. 2015). In general, low PBDE levels were detected in the present study. BDE-47, -99 and -154 were detected in more than 50\%, whereas BDE-209 was detected in $97 \%$ of the samples in all areas. Tetra-BDE (BDE- 47) and penta-BDE (BDE-99) are the most abundant, toxic, and bioaccumulative PBDE congeners (Ssebugere et al. 2014; Asante et al. 2013; Mwakalapa et al. 2018). Due to differences in metabolism, lower brominated congeners such as BDE 47 and 100 accumulate more in aquatic organisms, while higher brominated congeners like BDE 154 and 209 accumulate more in terrestrial organism (Luo et al. 2019). Deca-BDE, a mixture of nona-, octa and deca BDEs were used as a replacement for the tetra and penta- BDE mixtures after they got banned (Stockholm Convention 2021). However, deca-BDE debrominates to lower brominated and more persistent BDE congeners, such as BDE-47 (Stapleton et al. 2004). Half-life of BDE-209 may vary in different compartments. Luo et al. (2013) found that the dose dependent half-life of BDE-209 in the muscle of rice fish was from 17 to 19.4 days. Recent studies showed that there is a significant amount of gaseous BDE-209 in the global atmosphere, which is subject to longrange atmospheric transport (LRAT) (Li et al. 2017). The occurrence of BDE-209 in nearly 
$100 \%$ of the fish samples from Lake Kariba may therefore be explained by precipitation of atmospheric transported BDE-209, although the high median BDE-209 levels in site 2 (7.8 $\mathrm{ng} / \mathrm{g} \mathrm{lw}$ ) may suggest additional exposure from a local source. Median levels of BDE-47 and 99 were significantly higher in wild fish from site 1 and 2, compared to the farmed fish, strengthening the hypothesis that wild fish has been exposed to historic precipitation of atmospheric transported BDE-209. $\sum_{10} \mathrm{PBDE}$ levels in wild tilapia sites 1 and 2 were from four to thirteen-fold lower than in tilapia muscle from Lake Victoria but comparable to findings in the other lakes in Tanzania (Polder et al. 2014). They were in the same range as in tilapia from Ghana (Asante et al. 2013) and African tigerfish (Hydrocynus vittatus) from South Africa (Wepener et al. 2012), and tilapia in Uganda (Ssebugere et al. 2014), higher than in Milkfish (Chanos chanos) from Tanzania (Mwakalapa et al. 2018) but much lower than in trout (Salmo trutta) in Norway (Lyche et al. 2018) (Table 5). A global deca-BDE ban was adopted under the UN Stockholm Convention in 2017 and BDE-209 levels and its debromination products are thus expected to decrease in the environment.

\section{Levels and pattern of PFAS}

This is the first time PFASs are detected in fish from Zambia. PFASs is a large group of perfluorinated substances produced since the 1950 and because of their water repellant properties used in various consumer products such as impregnated outdoor textiles, shoes, food containers, kitchen ware and firefighting foam. They are very persistent to degradation and may cause adverse health effects in living species. In contrast to the lipophilic POPs, PFASs bind to proteins and are more soluble in water (Groffen et al. 2018; Gronnestad et al. 2017; Lam et al. 2014; Mudumbi et al. 2014). In the present study PFASs were only detected in wild tilapia in site 1 and 2, and not in site 3 and in farmed fish. PFDA and PFOS were both detected in levels >LOD in $100 \%$ of the tilapia from site 1 , and in $80 \%$ and $40 \%$ in site 2 , respectively (Fig. 3). PFNA was only found in one sample from site 1 and 2. The occurrence of PFASs in the wild fish from Sinazongwe (site 1), Gwembe (site 2) may be related to mining industries in the area. There are to our knowledge only two studies on PFASs in South African fish. Verhaert et al. (2017), who found comparable concentrations of PFOS, and PFNA in muscle tissue ranging from 0.15 to 2.7 , and <LOQ to $0.14 \mathrm{ng} / \mathrm{g}$ ww in muscle of fish from the Olifants River basin, while Groffen et al. (2018) found PFOS in fish liver from Vaal River in much higher levels similar or higher than in USA, Europe and Asia. than in European studies. PFOS levels in trout from the isolated large and deep inland Lake Femund, Norway, were 3.96 ng/g ww, 
thus 10 times higher than in tilapia from the present study (Lycke et al. 2018). The PFASs found in this study were long chained (>6C), of which PFOS are regulated under Stockholm Convention since 2009. These compounds are therefore expected to decline in the future.

\section{Possible implications for fish and human health}

In the present study, levels of PBDEs exceeded the European standard (EQS) for these contaminants in fish and may harm fish health (Table 4). Follow up studies are needed to ensure that international regulations result in decrease of these and other contaminants that threaten the aquatic environment. Dioxin-like (DL) PCB-118 TEQ levels (pg/g ww) were below EQS for DL-PCPs (Table 4). Liver tissues were used in this study because lipophilic POPs would show highest levels in the lipid rich liver. Results from this study can, therefore, not directly be used in a risk assessment for humans since humans consume fish muscle. However, the percentage of lipid in tilapia liver (range 3-19\%) (present study) is higher than in its muscle, (0.4-4 \%) (Polder et al. 2014), one can assume that POP levels in wild and farmed tilapia liver from the present study are much higher than in the muscle tissue. In 2011, the EU set an MRL for $\Sigma$ non-dioxin like (NDL) PCBs (PCB-28, -52, -101, -138, -153, and -180) in fish filet to 75 ng/g ww. The highest sum of $\Sigma$ NDL-PCBs in the present study (sum of PCB 118, 138, 153, 180) was $0.2 \mathrm{ng} / \mathrm{g}$ ww in liver, and thus far below this EU MRL. POP levels varied sometimes much between samples from the same area. This may have consequences when calculating risk in future studies, therefore analyzing of individual samples is recommended to get a better view on the variation in the specified areas.

\section{Conclusion}

The present study shows that levels of OCPs, PCBs, BFRs and PFAS are in general, lower in farmed fish compared to wild fish within the same lake. This indicates less risk for fish health in farmed than in wild fish. Farmed fish from this study is also considered safe for human consumption. There was a geographical trend with higher levels of DDTs, PCBs, PBDEs and PFASs from west to east of Lake Kariba. However, levels of HCB and HCHs were also higher in fish that had foraged near the farms, and this need further investigation to elucidate possible sources. The contribution of $p, p$ '-DDD to $\Sigma$ DDTs increased eastwards, possibly due to higher environmental impact of anaerobic processes. PCB levels were low, and PCB profiles dominated by the most persistent PCB congeners (PCB-118, -138, -153, -180), indicated exposure to historical used PCB, but to a different PCB mixture than in some other East African 
491

492

493

494

495

496

497

498

499

500

501

502

503

504

505

506

507

508

509

510

511

512

513

514

515

516

517

518

519

520

521

522

countries. The finding of the now banned PFOS and BDE-209 in the wild tilapia from the western part of the lake, warrant further research for determination of the possible sources.

\section{Acknowledgement}

We would like to thank the local Veterinary and Fisheries authorities in Gwembe, Siavonga and Sinazongwe district for their support, fishermen and fish farmers for assisting us with sample collection. We express our appreciation to Mahin Karimi and Mariska Hoorweg for assisting with the laboratory work and GC analysis.

\section{Funding}

The study was a part of TRAHESA project, A Capacity Building for Training and Research in Aquatic and Environmental Health in Eastern and Southern Africa, funded by NORAD Project (no.QAZ/0485 TAZ-13/0027).

\section{Declaration}

Conflict of interest: We declare no conflict of interest.

\section{References}

Ashraf MA (2017) Persistent organic pollutants (POPs): a global issue, a global challenge. Environ Sci Pollut Res 24:4223-4227.

Banda SF and Mundia AY (2009) An assessment of the demand for DDT (A case study for Zambia). Current World Environment 4:293-298.

Barni MFS, Ondarza PM, Gonzalez M, Da Cuna R, Meijide F, Grosman F, Sanzano P, Lo Nostro FL, Miglioranza KSB, 2016. Persistent organic pollutants (POPs) in fish with different feeding habits inhabiting a shallow lake ecosystem. Sci Total Environ 550:900-909.

Berg H, Martina K, Kautsky N (1992) DDT and Other Insecticides in the Lake Kariba Ecosystem, Zimbabwe. Ambio 21:444-450.

Brevik EM (1978) Bull Environ Contam Toxicol 19:281-286.

Brevik EM, Grande M, Knutzen J, Polder A, Skaare JU (1996) DDT contamination of fish and sediments from Lake Ørsjøen, Southern Norway: Comparison of data from 1975 and 1994. Chemosphere 33(11):2189-2200. 
Burreau S, Zebühr Y, Broman D, Ishaq, R (2004) Biomagnification of polychlorinated biphenyls (PCBs) and polybrominated diphenyl ethers (PBDEs) studied in pike (Esox lucius), perch (Perca fluviatilis) and roach (Rutilus rutilus) from the Baltic Sea. Chemosphere 55:1043-1052.

Bustnes JO, Lie E, Herzke D, Dempster T, Bjørn PA, Nygård T, Uglem I (2010) Salmon Farms as a Source of Organohalogenated Contaminants in Wild Fish. Environ Sci Technol 44:8736-8743.

Carubelli G, Fanelli R, Mariani G, Nichetti, S, Crosa G, Calamari D, Fattore, E (2007) PCB contamination in farmed and wild sea bass (Dicentrarchus labrax 1.) from a coastal wetland area in central Italy. Chemosphere 68:1630-1635.

Chen SH, Xu FL, Dawson R, Jiao XC, Tao S. Adsorption and absorption of dichlorodiphenyltrichloroethane (DDT) and metabolites (DDD and DDE) by rice roots. 2007. Environ Pollut 147:256-261.

Covaci A, Voorspoels S, Roosens L, Jacobs W, Blust R, Neels H (2008) Polybrominated diphenyl ethers (PBDEs) and polychlorinated biphenyls (PCBs) in human liver and adipose tissue samples from Belgium. Chemosphere 73: 170-175.

De Boer J, Van der Valk F, Kerkhoff MAT, Hagel P, Brinkman UAT (1994) An 8-Year Study on the Elimination of PCBs and Other Organochlorine Compounds from Eel (Anguilla anguilla) under Natural Conditions. Environ Sci Technol 28:2242-2248.

Deribe E, Rosseland BO, Borgstrom, R., Salbu B, Gebremariam, Z, Dadebo E., Norli, HR, Eklo, OM (2011) Bioaccumulation of persistent organic pollutants (POPs) in fish species from Lake Koka, Ethiopia: The influence of lipid content and trophic position. Sci Total Environ 410-411:136-145.

Eknath AE and Hulata G (2009) Use and exchange of genetic resources of Nile tilapia (Oreochromis niloticus). Reviews in Aquaculture 1:197-213. doi: 10.1111/j.17535131.2009.01017.x

EPA 2019. Environmental Protection Agency. PFOA, PFOS and Other PFASs. Basic Information on PFAS. https://www.epa.gov/pfas/basic-information-pfas. Accessed on 05/01/2022.

European Commission (2013) Directive 2013/39/EU of the european parliament and of the council of 12 August 2013 amending Directives 2000/60/EC and 2008/105/EC as regards priority substances in the field of water policy. Official Journal of the European Union. 
FAO (2018) The State of World Fisheries and Aquaculture - Meeting the Sustainable Development Goals. Rome.

FAO (2020) The State of World Fisheries and Aquaculture 2020. Sustainability in action.

$$
\text { Rome. https://doi.org/10.4060/ca9229en }
$$

Ferreira M, Caetano M, Antunes P, Costa J, Gil O, Bandarra N, Pousão-Ferreira P, Vale C, Reis-Henriques MA (2010). Assessment of contaminants and biomarkers of exposure in wild and farmed seabass. Ecotoxicol Environ Saf 73:579-588.

Gbeddy G, Glover E, Doyi I, Frimpong, S, Doamekpo L (2015). Assessment of Organochlorine Pesticides in Water, Sediment, African Cat fish and Nile tilapia, Consumer Exposure and Human Health Implications, Volta Lake, Ghana. J Environ Anal Toxicol, 5: 1-8.

Genschick S, Kaminski AM, Kefi AS, Cole SM (2017). Aquaculture in Zambia- An overview and evaluation of the sector's responsiveness to the needs of the poor. Penang, Malaysia: CGIAR Research Program on Fish Agri-Food Systems and Lusaka, Zambia: Department of Fisheries. Working Paper: FISH-2017-08.

Golden CD, Seto KL, Dey MM, Chen OL, Gephart JA, Myers SS, Smith M, Vaitla B, Allison EH (2017). Does Aquaculture Support the Needs of Nutritionally Vulnerable Nations? Front Mar Sci 4:1-7.

Groffen T, Wepener V, Malherbe W, Bervoets L (2018) Distribution of perfluorinated compounds (PFASs) in the aquatic environment of the industrially polluted Vaal River, South Africa. Sci Tot Environ 627:1334-1344.

Gronnestad R, Villanger GD, Polder A, Kovacs KM Lydersen, C, Jenssen BM , Borga K (2017). Maternal transfer of perfluoroalkyl substances in hooded seals. Environ Toxicol Chem, 36:763-770.

Hasimuna OJ, Maulu S, Monde C, Mweemba M, Cage aquaculture production in Zambia: Assessment of opportunities and challenges on Lake Kariba, Siavonga district. 2019. The Egypt J Aquat Res 45(3):281-285

Hayward D Wong J, Krynitsky AJ (2007). Polybrominated diphenyl ethers and polychlorinated biphenyls in commercially wild caught and farm-raised fish fillets in the United States. Environ Res 103:46-54.

HenryL and Kishimba MA (2006). Pesticide residues in Nile tilapia (Oreochromis niloticus) and Nile perch (Lates niloticus) from Southern Lake Victoria, Tanzania. Environ Pollut 140:348-354. 
Jarić I, Višnjić-Jeftić Ž, Cvijanović G, Gačić Z, Jovanović L, Skorić S, Lenhardt M (2011). Determination of differential heavy metal and trace element accumulation in liver, gills, intestine and muscle of sterlet (Acipenser ruthenus) from the Danube River in Serbia by ICP-OES. Microchem J 98:77-81.

Jürgens MD Chaemfa C, Hughes D, Johnson AC, JonesKC (2015). PCB and organochlorine pesticide burden in eels in the lower Thames River (UK). Chemosphere 118:103-111.

Kalantzi I, Shimmield TM, Pergantis SA, Papageorgiou N, Black KD, Karakassis I (2013) Heavy metals, trace elements and sediment geochemistry at four Mediterranean fish farms. Sci Total Environ 444:128-37.

Kidd KA, Stern G, LemoalleJ (2004) Mercury and Other Contaminants in Fish from Lake Chad, Africa. Bull Environ Contam Toxicol 73:249-256.

Kishimba MA, Henry L, Mwevura H, Mmochi AJ, Mihale M, Hellar H (2004) The status of pesticide pollution in Tanzania. Talanta 64:48-53.

Lam N-H, Cho C-R, Lee J-S, Soh H-Y, Lee B-C, Lee J-A, Tatarozako N, Sasaki, K, Saito N, Iwabuchi K, Kannan K, Cho H-S (2014). Perfluorinated alkyl substances in water, sediment, plankton and fish from Korean rivers and lakes: A nationwide survey. Sci Tot Environ 491-492:154-162.

Letcher RJ, Bustnes JO, Dietz R, Jenssen BM, Jorgensen EH, Sonne C, Verreault J, Vijayan MM, Gabrielsen GW (2010). Exposure and effects assessment of persistent organohalogen contaminants in arctic wildlife and fish. Sci Total Environ 408:29953043.

Li X, Li J, Wang Y, Fu L, Fu Y, Li B, Jiao B (2011). Aquaculture Industry in China: Current State, Challenges, and Outlook. Rev Fish Sci 19:187-200.

Lundebye A-K, Lock E-J, Rasinger JD, Nøstbakken OJ, Hannisdal R, Karlsbakk E, Wennevik V, Madhun A S, Madsen L, Graff IE, Ørnsrud R (2017). Lower levels of Persistent Organic Pollutants, metals and the marine omega 3-fatty acid DHA in farmed compared to wild Atlantic salmon (Salmo salar). Environ Res 155:49-59.

Luo Y-L, Luo X-J, Ye M-X, Lin L. Zeng Y-H, Mai B-X (2019) Species-specific debromination of polybromodiphenyl ethers determined by deiodinase activity in fish. Environ Pollut 246:710-716.

Lycke JL, Berg V, Kallenborn R (2018) | 2018 Prioriterte miljøgifter i norsk ferskvannsfisk 2013-2016 (EU Priority pollutants in Norwegian fresh water fish 2013-2016). Report Miljøovervåkning M-1075. 
Lyche JL, Rosseland C, Berge G, Polder A (2015) Human health risk associated with brominated flame-retardants (BFRs). Environ Int 74:170-180.

Mdegela RH, Braathen M, Pereka AE, Mosha RD, Sandvik M, Skaare JU (2009). Heavy Metals and Organochlorine Residues in Water, Sediments, and Fish in Aquatic Ecosystems in Urban and Peri-Urban Areas in Tanzania. Water Air Soil Pollut 203:369-379

Meng X-Z, Yu L, Guo Y, Ma, B-X, Zeng EY (2008). Congener-specific distribution of polybrominated diphenyl ethers in fish of China: Implication for input sources. Environ Toxicol Chem 27:67-72.

Mhlanga L, Phiri C, Chifamba P (2014) Challenges surrounding water management within Lake Kariba environs. In: Mhlanga L KN, Haller T (eds.) Fragmentation of Natural Resources Management: Experiences from Lake Kariba Lit-Verlag Switzerland: PLAAS.

Mudumbi JBN, NtwampeS., Muganza FM, Okonkwo O (2014) Perfluorooctanoate and perfluorooctane sulfonate in South African river water. Water Sci Technol 69:185-94.

Mwakalapa EB, Mmochi AJ, Müller MHB, Mdegela RH, Lyche JL, Polder A (2018). Occurrence and levels of persistent organic pollutants (POPs) in farmed and wild marine fish from Tanzania. A pilot study. Chemosphere 191:438-449.

Nie XP, Lan CY, An TC, Wong MH, Li KB (2006). Distributions and Congener Patterns of PCBs in Fish from Major Aquaculture Areas in the Pearl River Delta, South China. Hum Ecol Risk Assess: An Int J 12:363-373.

Nieuwoudt C, Quinn LP, Pieters R, Jordaan I, Visser M, Kylin H, Borgen AR, Giesy JP, Bouwman H (2009). Dioxin-like chemicals in soil and sediment from residential and industrial areas in central South Africa. Chemosphere 76:774-783

Nonga HE, Mdegela RH, Lie E, SandvikM., Skaare JU (2011). Assessment of farming practices and uses of agrochemicals in Lake Manyara basin, Tanzania. Afr J Agric Res 6:2216-2230.

Panseri S, Chiesa L, Ghisleni G, Marano G, Boracchi P, Ranghieri V, Malandra RM, Roccabianca P, Tecilla M (2019). Persistent organic pollutants in fish: biomonitoring and cocktail effect with implications for food safety. Food Addit Contam Part A Chem Anal Control Expo Risk Assess 36:601-611.

Pius C, Sichilongo K, Mswela PK, Dikinya O (2019) Monitoring polychlorinated dibenzo-pdioxins/dibenzofurans and dioxin-like polychlorinated biphenyls in Africa since the 

implementation of the Stockholm Convention — an overview. Environ Sci Pollut Res 26:101-113.

Polder A, Müller MB, Lyche JL, Mdegela RH Nonga HE., Mabiki FP, Mbise TJ, Skaare JU, Sandvik M, Skjerve E, Lie E (2014). Levels and patterns of persistent organic pollutants (POPs) in tilapia (Oreochromis sp.) from four different lakes in Tanzania: geographical differences and implications for human health. Sci Total Environ 488 489:252-260.

Polder A, Müller M B, Brynildsrud O B, De Boer J, Hamers T, Kamstra JH, Lie E, Mdegela RH, Moberg H, Nonga HE, Sandvik M, Skaare JU, Lyche JL (2016). Dioxins, PCBs, chlorinated pesticides and brominated flame retardants in free-range chicken eggs from peri-urban areas in Arusha, Tanzania: Levels and implications for human health. Sci Tot Environ 551-552:656-667.

Porte C, Janer G, Lorusso LC, Ortiz-Zarragoitia M, Cajaraville MP, Fossi MC, Canesi L (2006). Endocrine disruptors in marine organisms: Approaches and perspectives. Comparative Biochemistry and Physiology Part C: Toxicol Pharmacol 143:303-315.

Renieri EA, Goumenou M, Kardonsky DA, Veselov VV, Alegakis AK, Buha A, Tzatzarakis MN, Nosyrev AE, Rakitskii VN., Kentouri M, Tsatsakis A (2019). Indicator PCBs in farmed and wild fish in Greece - Risk assessment for the Greek population. Food Chem Toxicol 127:260-269.

Rodriguez-Hernandez A, Camacho M, Henriquez-Hernandez LA, Boada LD, Valeron PF, Zaccaroni A, Zumbado M, Almeida-Gonzalez M, Rial-Berriel C, Luzardo OP (2017) Comparative study of the intake of toxic persistent and semi persistent pollutants through the consumption of fish and seafood from two modes of production (wildcaught and farmed). Sci Total Environ 575:919-931.

Saavedra M, Pereira TG, Carvalho LM, Pousão-Ferreira P, Grade A, Teixeira B, QuentalFerreira H, Mendes R, Bandarra N, Gonçalves A (2017) Wild and farmed meagre, Argyrosomus regius : A nutritional, sensory and histological assessment of quality differences. J Food Compos Anal 63:8-14.

SEAFDEC 1991. Southeast Asian Fisheries Development Center, Aquaculture DepartmentComparing nutrients in wild and farmed fish. Aqua Farm News 9:4-7.Santonen T, Nielsen G, Papameletiou D, Klein C (2017) SCOEL/REC/188 Hexachlorobenzene Recommendation from the Scientific Committee on Occupational Exposure Limits. 
Serrano R, Blanes MA, Lopez FJ (2008). Biomagnification of organochlorine pollutants in farmed and wild gilthead sea bream (Sparus aurata) and stable isotope characterization of the trophic chains. Sci Total Environ 389:340-9.

Sharma CM, Rosseland BO, Almvik M, Eklo OM (2009). Bioaccumulation of organochlorine pollutants in the fish community in Lake Årungen, Norway. EnvironPollut 157:2452-2458.

Squadrone S, Favaro L, Prearo M, Vivaldi B, Brizio P, Abete MC (2013) NDL-PCBs in muscle of the European catfish (Silurus glanis): An alert from Italian rivers. Chemosphere 93:521-525.

Ssebugere P, Kiremire BT, Kishimba M, Wandiga SO, Nyanzi SA, Wasswa J (2009) DDT and metabolites in fish from Lake Edward, Uganda. Chemosphere, 76:212-5.

Ssebugere P, Sillanpää M, Wang P, Li Y, Kiremire BT, Kasozi GN, Zhu C, Ren D, Shang H, Zhang Q, Jiang G (2014) Polychlorinated dibenzo-p-dioxins, polychlorinated dibenzofurans and polybrominated diphenyl ethers in sediments and fish species from the Murchison Bay of Lake Victoria, Uganda. Sci Tot Environ 500-501:1-10.

Stapleton HM, Letcher RJ, Baker JE (2004) Debromination of Polybrominated Diphenyl Ether Congeners BDE 99 and BDE 183 in the Intestinal Tract of the Common Carp (Cyprinus carpio). Environ Sci Technol 38:1054-1061.

Subasinghe RP (2005) Epidemiological approach to aquatic animal health management: opportunities and challenges for developing countries to increase aquatic production through aquaculture. Prev Vet Med 67:117-124.

Stockholm Convention (2021) Stockholm Convention on Persistent Organic Pollutants. Available at http:// chm. pops. int, Accessed 5 Januari 2022.

Sun Y-X, Hao Q, Xu X-R, Luo X-J, Wang S-L, Zhang Z-W, Mai B-X (2014) Persistent organic pollutants in marine fish from Yongxing Island, South China Sea: Levels, composition profiles and human dietary exposure assessment. Chemosphere 98:84-90.

Varol M (2019) Impacts of cage fish farms in a large reservoir on water and sediment chemistry Environ Pollut 252:1448-1454.

Van den Berg M, Birnbaum LS, Denison M, De Vito M, Farland W, Feeley M, Fiedler H, Hakansson H, Hanberg A, Haws L, Rose M, Safe S, Schrenk D, Tohyama C, Tritscher A, Tuomisto J, Tysklind M, Walker N, Peterson R (2006) Review. 2006. The 2005 World Health Organization Reevaluation of Human and Mammalian Toxic Equivalency Factors for Dioxins and Dioxin-Like Compounds. Toxicol Sci 93(2):223241. 
Verhaert V, Covaci A, Bouillon S, Abrantes K, Musibono D, Bervoets L, Verheyen E, Blust R (2013) Baseline levels and trophic transfer of persistent organic pollutants in sediments and biota from the Congo River Basin (DR Congo). Environ Int 59:290-302. VKM Report 15. Benefit-risk assessment of fish and fish products in the Norwegian diet - an update. Scientific Opinion of the Scientific Steering Committee. [293 pp], ISBN: 978-82-8259-159-1, Oslo, Norway.

Vijgen J, de Borst B, Weber R, Stobiecki T, Forter M (2019) HCH and lindane contaminated sites: European and global need for a permanent solution for a long-time neglected issue. Environ Pollut 248 :696-705.

Wang G, Lu Y, Han J, Luo W, Shi Y, Wang T, Sun Y (2010) Hexachlorobenzene sources, levels and human exposure in the environment of China. Environ Int 36:122-130.

Wania, F., Mackay, D. 1993. Global Fractionation and Cold Condensation of Low Volatility Organochlorine Compounds in Polar Regions Ambio, 22.

WHO 2011. DDT in indoor residual spraying: human health aspects. Environmental Health Criteria 241). ISBN 978924157241 5; ISSN 0250-863X.

WorldFish 2022. https://www.worldfishcenter.org/where-we-work/africa/zambia. Accessed 5 January 2022.

Zambia, 2012. 2010 Census of Population and Housing. National Analytical Report. Central Statistical Office 2012. https://www.zamstats.gov.zm/phocadownload/2010_Census/2010\%20Census\%20of\%2 0Population\%20National\%20Analytical\%20Report.pdf . Accessed 5 Januari 2022. 
Figures

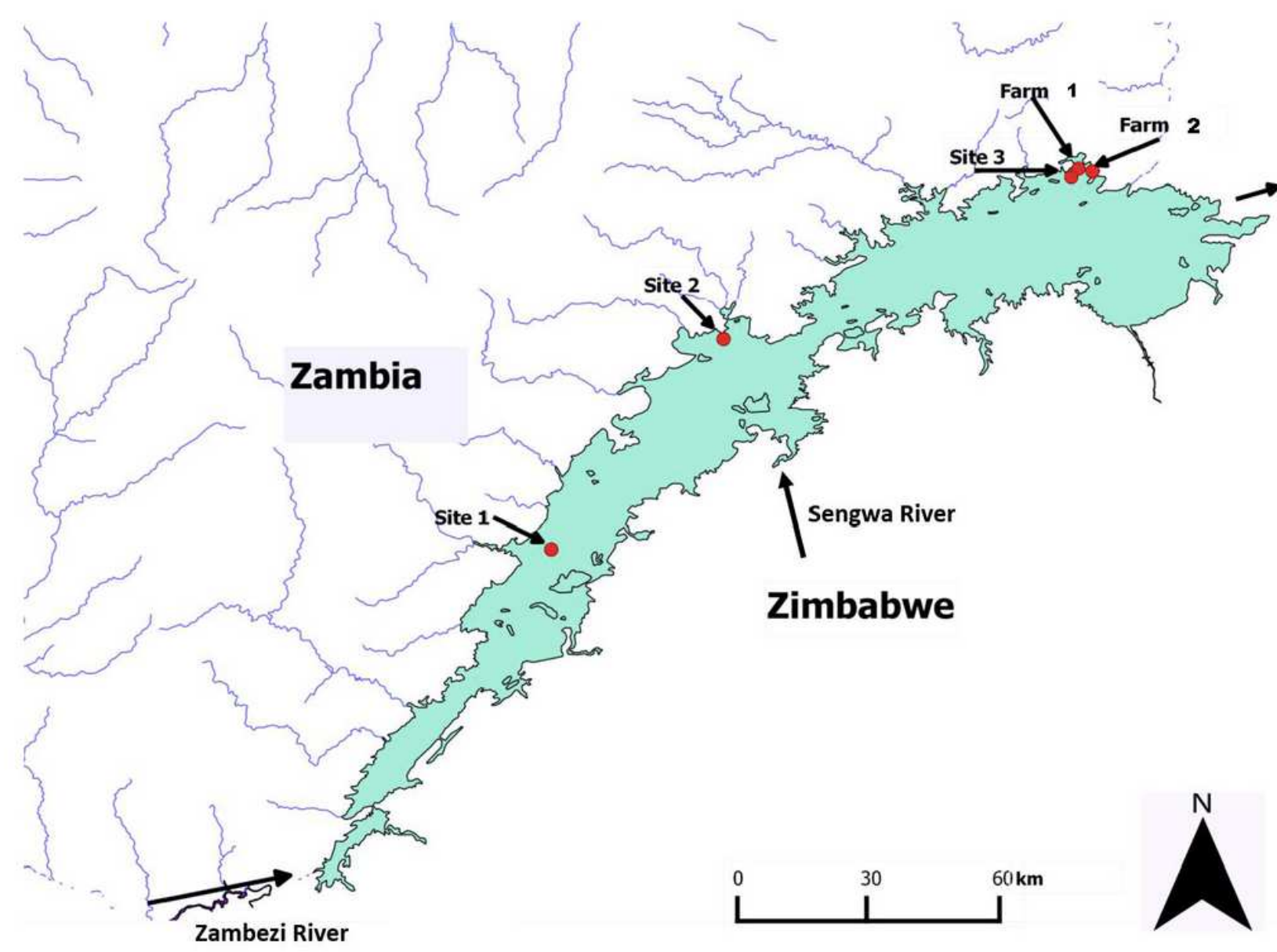

Figure 1

Map of lake Kariba, showing the 5 sampling locations (sites1-3 and farms 1 and 2) 

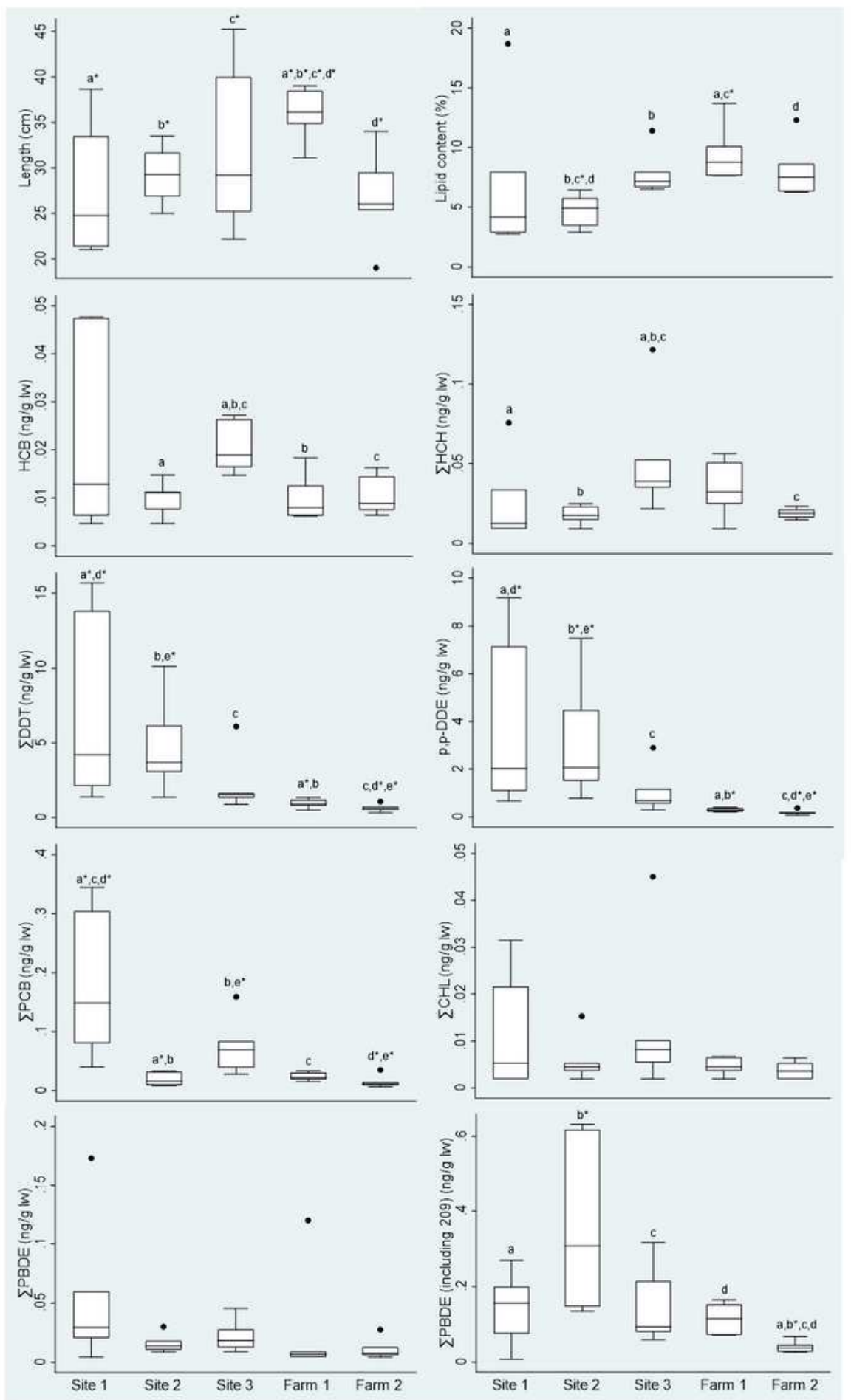

\section{Figure 2}

Fish length, liver lipid content and contaminant concentrations in livers from wild fish (site 1-3) and farmed fish (farm 1-2) in Lake Kariba, Zambia. Fish length is given in $\mathrm{cm}$, liver lipid content in \% and liver concentrations are presented as ng/g lipid weight. Box plots show median (line), IQR (box) and minimum to maximum (whiskers). Statistical differences were determined using Kruskal Wallis with Dunn`s post hoc test with and without Bonferroni's corrections for multiple testing. Letters (a-e) indicate statistically 
significant difference $(p<0.05)$ between the sites and farms. Asterisk $\left(^{*}\right)$ indicates statistical significance $(p<0.05)$ after Bonferroni's corrections for multiple testing.
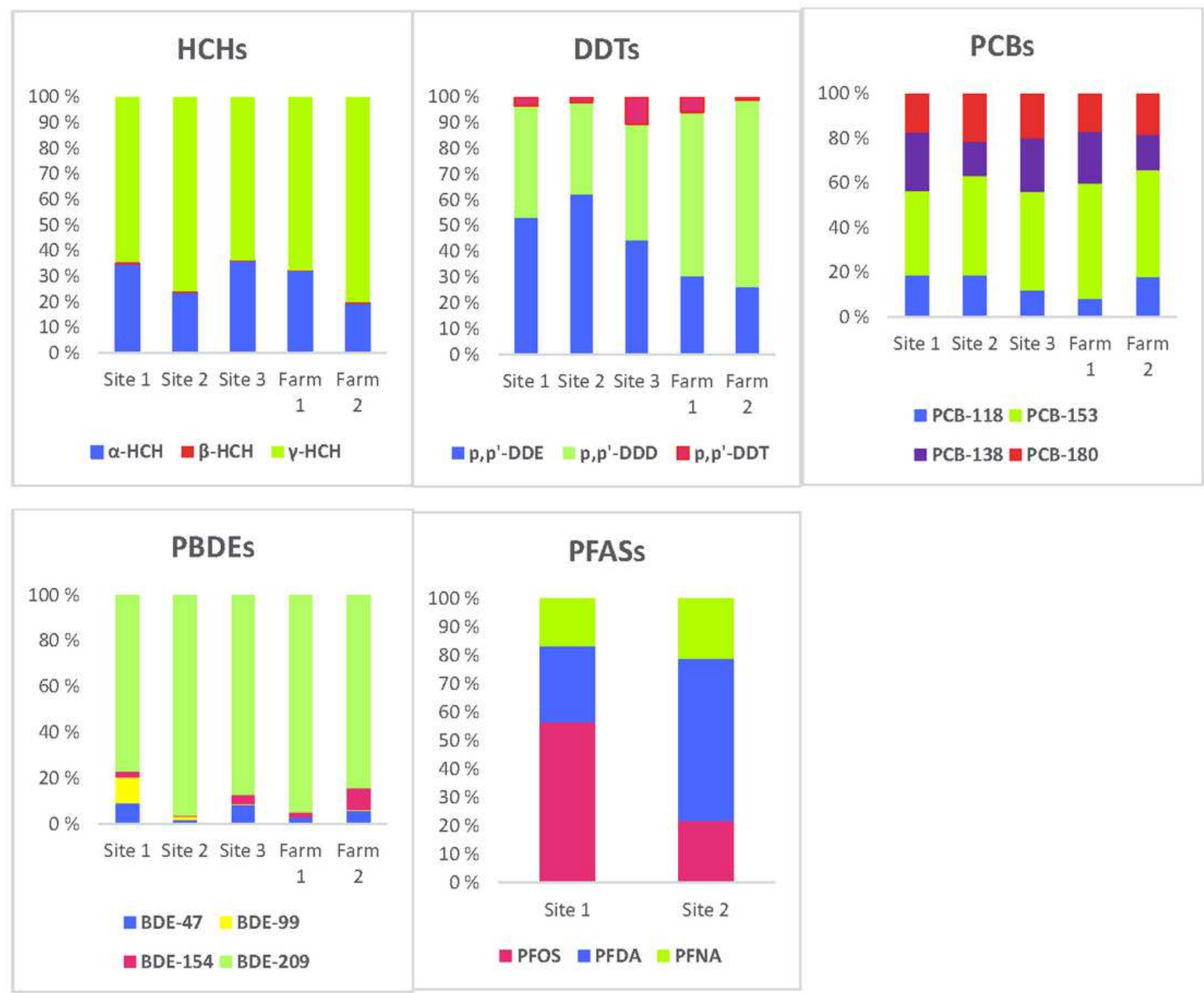

\section{Figure 3}

Percent contribution of individual congeners to $\Sigma \mathrm{HCHs}, \Sigma \mathrm{DDTs}, \Sigma \mathrm{CHLs}, \Sigma \mathrm{PCBs}, \Sigma \mathrm{PBDEs}$ and PFASs

\section{Supplementary Files}

This is a list of supplementary files associated with this preprint. Click to download.

- Tables15.pdf

- SupplementaltablesS1.11.2andfiguresS1.pdf 